УДК: 323.173(497.115):316.644-057.875

(497.11 Beograd)(497.5 Zagreb)

DOI: https://doi.org/10.22182/pnb.1812020.9

Оригинални научни рад
Политика националне безбедности

Година XI, vol. 18

број $1 / 2020$.

стр. 201-219

\title{
Wiktor Hebda*
}

Institute of Political Science and International Relations, Jagiellonian University, Krakow, Poland

\section{KOSOVO STATUS ACCORDING TO STUDENTS OF THE UNIVERSITY OF ZAGREB AND THE UNIVERSITY OF BELGRADE}

\begin{abstract}
Kosovo independence still remains a key issue on a global scale. In simple terms, there are two contradictory stands on the sovereignty of Kosovo. According to the first one, Kosovo declaration of independence is illegal due to the breach of international law and the constitution of the Republic of Serbia of 2006. Meanwhile the second stand proves that unilateral Kosovo declaration of independence was legal since Kosovo Albanians are fully entitled to the right of self-determination. The following paper presents an opinion on Kosovo independence expressed by the students of the Faculty of Political Science at the University of Belgrade and the University of Zagreb - two most important universities in Serbia and Croatia. The results presented in the paper are based on the survey carried out by the author in 2013.
\end{abstract}

Keywords: Kosovo, Croatia, Serbia, sovereignty, territorial integrity

wiktor.hebda@uj.edu.pl 


\section{INTRODUCTION}

Acting upon the unilateral declaration of independence, Kosovo proclaimed its sovereignty on 17 February 2008 but its independence is still raising some serious doubts not only in Serbia but also in Europe and in the world. More than a decade later the international community continues to be divided into those who recognize Kosovo sovereignty and the ones who refuse to agree on the matter. There are various reasons for such a state of affairs. Numerous arguments support Kosovo sovereignty but there are also multiple disadvantages which point out to the breach of both national (Serbian) and international law. On one hand stands the right of self-determination of nation but on the other, there is the principle of territorial integrity guaranteed by Serbian constitution and various regulations of international law. The issue is still highly controversial and therefore influences the politics on international level.

Thanks to the survey on Kosovo independence conducted among the students of the University of Belgrade and the University of Zagreb, the following article can focus not only on legal or political discourse but also on sociological perspective. It is expected that the research will show how young students of political science from Croatia and Serbia perceive the issue of Kosovo. The research took form of a comparative study. Serbian students who live in a country directly affected by the "Kosovo crisis" are contrasted with students from Croatia who are not directly connected with the "Kosovo crisis".

The main thesis of the paper comes down to the claim that in terms of Kosovo sovereignty the opinion of young people (students) overlaps with the official stand of the authorities of a given country (either Serbia or Croatia). It should be strongly emphasized that 25 years after the end of Cold War and 15 years after the end of Yugoslav conflicts, the young people of the region still couldn't reach consensus over basic security issues in the region. Now, in 2020 , some of these students directly or indirectly (f. e. as analysts, experts, advisers, politicians, scientists, journalists, government officials etc.) influence the policy of their countries, which is why 
their view of Kosovo status is very important for security not only Serbia or Croatia but also of the whole CEE region.

\section{RESEARCH METHODOLOGY}

\section{Research hypotheses}

a) The students of the Faculty of Political Science at the University of Zagreb present a positive stand on Kosovo independence

b) The students of the Faculty of Political Science at the University of Belgrade present a negative stand on Kosovo independence

\section{Research tools}

The questionnaire used in the study consisted of 45 questions divided into 5 topics. The vast majority of the questions were multiple choice questions. The remaining ones were open with an option to write own answer. The first part of the questionnaire contained introductory questions. The second part referred to Serbian-Croatian relations until the year 1991. The third one was connected with the civil war in Yugoslavia. The fourth part was about post-war issues. Finally, the last one was devoted to selected issues in Serbian and Croatian politics. This part included questions about Kosovo which were used in this paper. The questionnaire also contained a part with respondent's particulars required for the purposes of the study.

\section{Research group}

The study was carried out among full-time students of the Faculty of Political Science at the University of Zagreb and the University of Belgrade (under- and post-graduate studies). In Zagreb the students of political studies and journalism were surveyed while in Belgrade, since the university can offer a wider range of courses, the research included the following specializations: political studies, international relations and journalism. Taking into consideration the aim of the study, the research group was selected with respect to specialization and type of studies. 
The survey was conducted in 2013. Firstly (between March and June 2013), the students from Zagreb were examined and then (October - December 2013) the students from Belgrade. There were 320 full-time students involved in the survey (160 in each country).

In the research carried out in Zagreb $36 \%$ of the students were from political studies and $64 \%$ were journalism students. At the University of Belgrade there were respectively $40 \%$ of political studies participants, $20 \%$ of international relations students and $40 \%$ of journalism students.

The respondents also varied in terms of the following factors: gender, age, marital status, place of living and nationality.

The Zagreb group consisted of: $75 \%$ women and $25 \%$ men; $82 \%$ aged $19-24,17 \%$ aged $25-30,1 \%$ aged $31-35$ years old, in terms of marital status they were in $92.5 \%$ single and $7.5 \%$ of different status; $44 \%$ were students who lived in cities over 100,000 inhabitants, $4.5 \%$ lived in towns smaller than 100.000 inhabitants, $37 \%$ smaller than 50.000 and $14.5 \%$ lived in a village. With respect to the place of living: $44.5 \%$ lived in Zagreb and Zagreb County, 5.5\% came from Split-Dalmatia County, 5\% from both Zadar County and Osijek-Baranja County and remaining 5\% from other counties. Nationality wise: $96 \%$ declared Croatian nationality, 2\% mixed, one person was Albanian, one Serbian and one Slovenian.

In the Belgrade group there were: $64 \%$ of women and $36 \%$ men; $98 \%$ aged $19-24,2 \%$ aged $25-30$; in terms of marital status there were $94 \%$ single and $6 \%$ of a different status; $58 \%$ were students who lived in cities over 100,000 inhabitants, $17 \%$ lived in towns smaller than 100.000 inhabitants, $18 \%$ smaller than 50.000 and $7 \%$ lived in a village. With respect to the place of living: $85 \%$ lived in Central Serbia (45\% were from Belgrade and Belgrade District), $10 \%$ came from Vojvodina and 5\% from Kosovo. Nationality wise: $95 \%$ declared Serbian nationality, 3\% mixed and 2\% Montenegrin. 
Chart 1. Gender of the research group

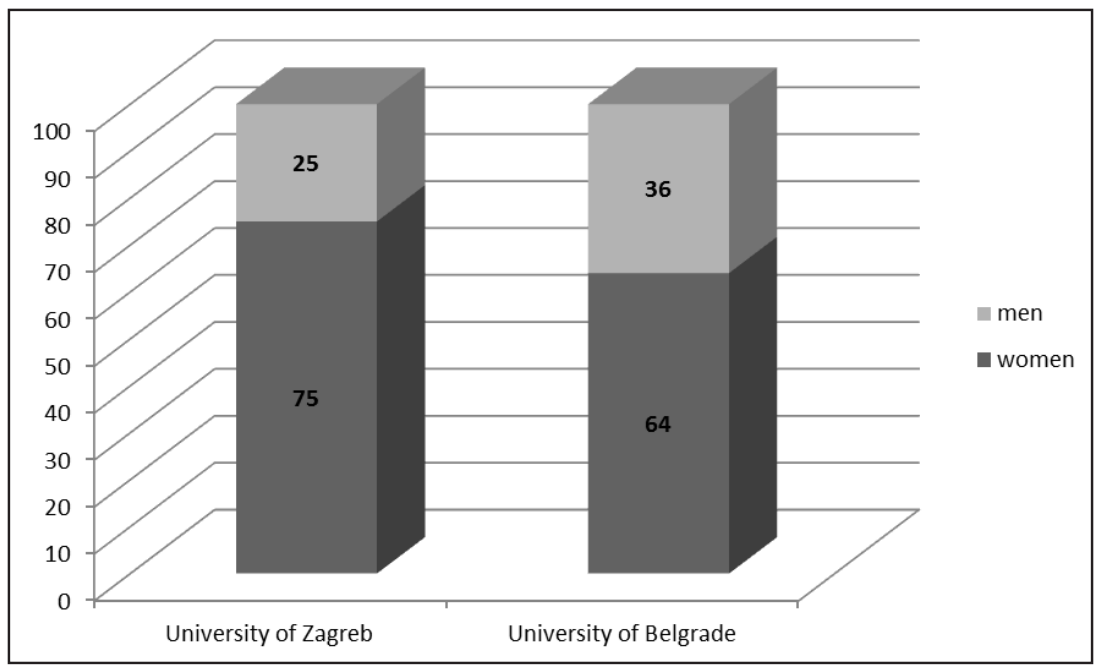

Chart 2. Nationality of the research group

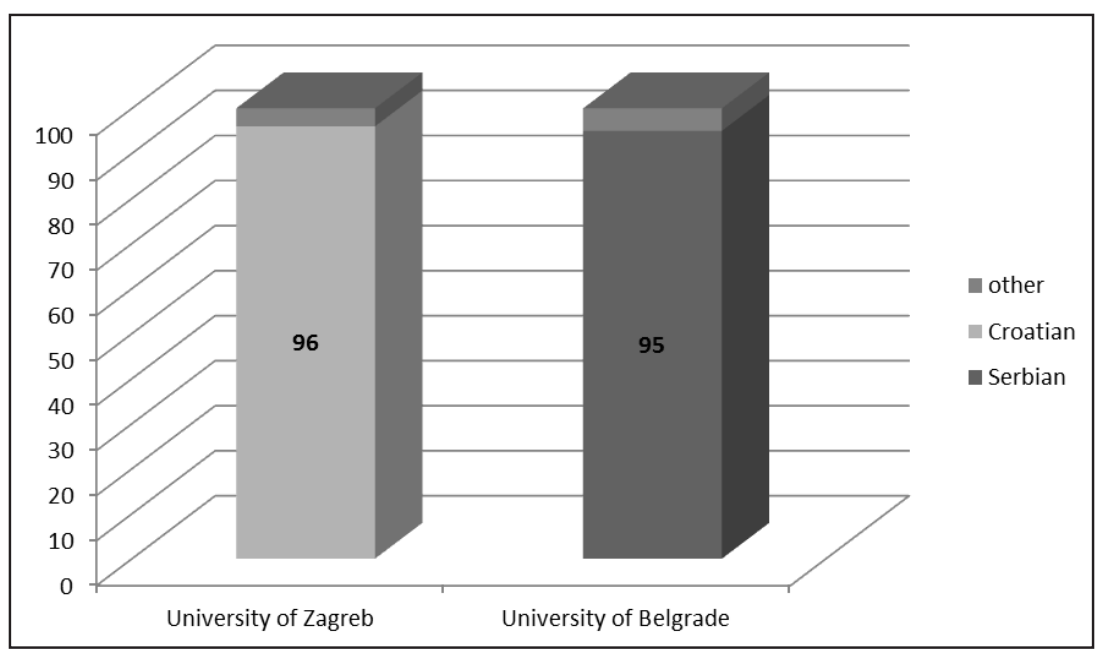




\section{SERBIA AND CROATIA FACING THE PROBLEM OF KOSOVO SOVEREIGNTY}

State authorities of Serbia and Croatia express a contrasting viewpoint on the matter of Kosovo independence. According to Serbia, Kosovo declared its sovereignty illegally. Serbian authorities claim that unilateral declaration of Kosovo independence violated the internal law of the state - the Constitution of the Republic of Serbia of 2006. According to the preamble, the article 114 and the article 182, Kosovo is an integral part of the territory of Serbia forming the Autonomous province of Kosovo and Metohija (Ustav Republike Srbije 2006). The Serbs also point out to the fact that the declaration of Kosovo independence violates international law and Resolution 1244 (Крга 2017: 57; Гаћиновић 2017: 74; Петров 2018: 13; Даниловић \& Благојевић Даниловић 2019: 160 - 162). In compliance with the United Nations Security Council Resolution 1244, Serbia's agreement is an absolute must for Kosovo secession (formerly the Federal Republic of Yugoslavia FRY). The legitimacy of this condition is also questioned, though. The doubts mostly concern the principle of territorial integrity of Serbia (FRY) being mentioned only in the preamble of Resolution 1244 (Cerone 2008: 68), not in the main body of the document, but, in fact, references to the integrity of Serbia (FRY) do appear in the main part of Resolution. According the article 1, the Security Council "decides that a political solution to the Kosovo crisis shall be based on the general principles in annex 1 and as further elaborated in the principles and other required elements in annex 2 ". Both annexes contain references to the principle of territorial integrity and it seems that they include rules which constitute the basis for solving the problem of Kosovo (Jovanović 2008: 137). The supporters of "illegal Kosovo" also argue that Kosovo declared its independence disregarding the necessity to hold an international conference which was supposed to lay down the conditions of such an act. In this way the provisions of Rambouillet Accords were violated (Interim Agreement for Peace and Self-Government in Kosovo 1999). In fact, both the ultimatum and Resolution do mention "the agreement", which proves that it is necessary for all the parties involved, Serbia in particular, to agree on the matter (Komorowski 2011: 66). All these arguments reveal only a small 
part of the discussion on Serbia's viewpoint on Kosovo independence, which, according to Serbian authorities stands against the law.

However, Croatian authorities maintain a strikingly different stance on this very same case. Firstly, the then cabinet of Sanader reacted positively to Kosovo declaration of independence, which led to Croatian recognition of Kosovo sovereignty on 19 March 2008. Stjepan Mesić, the president between 2000 and 2010, also took the same stance. In 2010 he even came to Pristina and met with Kosovo authorities (Hebda 2018: 281). In the following years, the president Kolinda Grabar - Kitarović and subsequent Croatian cabinets pursued the policy of promoting Kosovo as an independent state. To justify their viewpoint, Croatian authorities presented the arguments that were also put forward by other countries which recognized Kosovo independence. The arguments are mostly based on the principle of nations to self-determination (Crnić - Grotić \& Kasipović 2013: 895 - 910; Sterio 2010: $361-365$ ) as well as the advisory opinion on the declaration of independence in respect to Kosovo issued by the International Court of Justice in July 2010 (International Court of Justice 2010).

\section{KOSOVO INDEPENDENCE ACCORDING TO THE STUDENTS OF THE UNIVERSITY OF ZAGREB AND THE UNIVERSITY OF BELGRADE - RESULTS OF THE RESEARCH}

Taking into consideration the standpoint adopted by Serbian and Croatian authorities on Kosovo independence, it is interesting to know how the government's official line influence the public opinion in both countries. Both Croatia and Serbia are now democratic countries so state authorities should pursue the will of their citizens. The question of Kosovo independence has been discussed not only on international or political grounds but also on social level (both in specialized and non-specialized groups). This case remains crucial to the security of Serbia and the whole Balkan region, thus the reasoning for either recognizing or rejecting Kosovo independence is inconclusive. It is therefore interesting to take into consideration opinions of young people, political science students in particular, who in the future might form political elites 
or influence decisions of state authorities (political parties, NGO, lobbying organizations, etc.). It seems that in the next years, or even decades, Kosovo might have a strong influence on international relations in the Balkans. Therefore, it is essential to define the approach of young people who might shape the opinion on the so-called Kosovo precedent.

The study shall begin with the analysis of students' opinion on the declaration of independence proclaimed by Kosovo on 17 February 2008. The research shows that the students of the University of Zagreb clearly argued in favor of Kosovo sovereignty, showing $78 \%$ of support. Only $7 \%$ had a contrary opinion while $15 \%$ were unable to define their position on the matter. It points to the conclusion that students' opinion was in sync with the decision made by Croatian authorities to recognize Kosovo independence. Although several years had passed since the events of 2008, the research group was still deeply convinced of legitimacy of Kosovo independence. On one hand, the problem of Kosovo status might seem to be quite irrelevant for the students from Zagreb since Croatia is not directly connected with the issue. However, political and social relations between Serbia and Croatia are still so strained that they might have influenced young people's opinion on current Serbian politics (Hebda 2018: 225 - 241). One shall also remember that Yugoslavia breakup resulted from the civil war which was spurred by Serbian-Croatian conflict during the years 1991-1995. Due to that fact, a part of Croatian society might feel an "emotional bond" with Kosovo Albanians, especially when it comes to the conflict in Kosovo in 1999. Croatians also continue to have difficult relations with Serb minority spread in some parts of the country (Petričušić 2009: 14 - 20). There are many factors damaging relations between Serbia and Croatia and they are frequently used by political elites of both countries.

The students of the University of Belgrade, however, perceive Kosovo independence in a much different way. The vast majority of the research group (83\%) expressed an opinion which was in sync with the official line of Serbian government disapproving of Kosovo independence. Historically wise, Kosovo is a cradle of Serbian civilization. Here, Serbian statehood had been shaped throughout many centuries and it is still an important sacral and cultural centre for people (Avramović et al. 2010). Since histor- 
ical memory plays a vital role in nations' existence, Kosovo still remains visibly present in Serbian politics and culture (Гаћиновић 2017: 77 - 84). Nevertheless, one in ten of the surveyed argued that Kosovo should be independent which shows that a part of Serbian youth expresses an opinion contradictory to the official position of state authorities. Such an opinion might be caused by various aspects and it is rather impossible to draw any constructive conclusion in this paper. According to some media coverage and specialized or scientific analyses, a part of Serbian society claims that keeping Kosovo within the borders of Serbia poses economic and social problems. The area is mostly inhabited by Albanians who are perceived as back-looking and economically underdeveloped, which, in turn, puts a huge load on Serbian state. This opinion is naturally exaggerated and calls for further research.

Chart 3. Should Kosovo be independent?

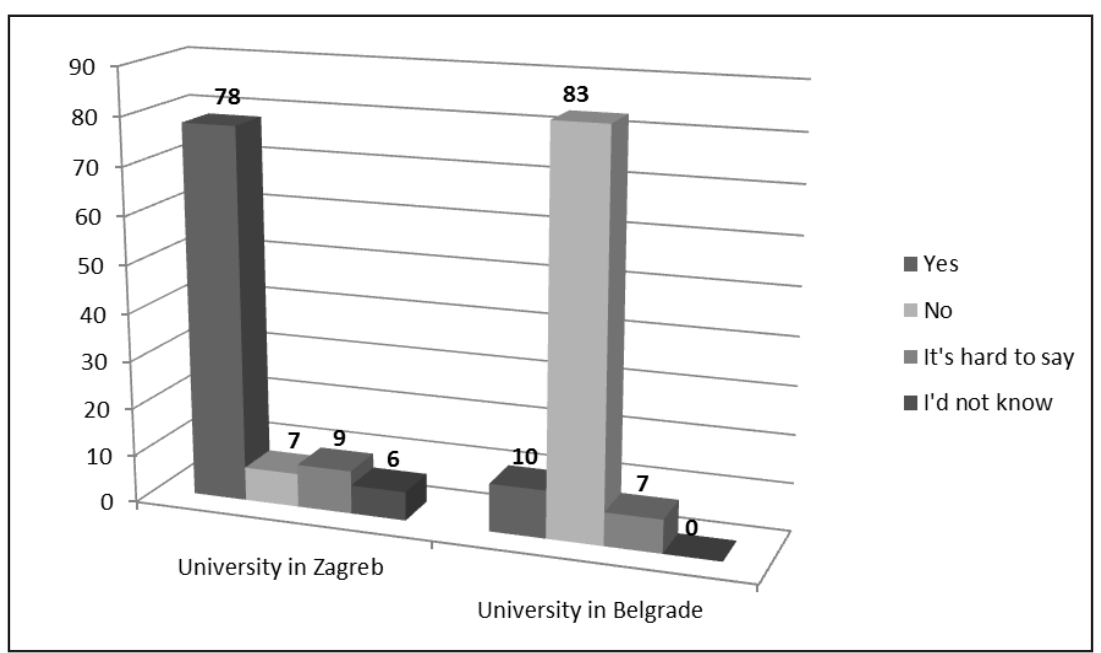

For more than a decade Kosovo has remained an area beyond Serbian jurisdiction and this has raised serious doubts in respect to the shape and quality of its political, economic and social system. The research group from the University of Zagreb presented really contrasting viewpoints on that matter. $33 \%$ of the respondents claimed that within the next 10 years Kosovo would not be a stable and democratic country. Meanwhile 32\% expressed a contrary 
opinion (i.e. Kosovo would be a stable and democratic country) and $30 \%$ argued that it was difficult to define which direction Kosovo would follow. The presented results might suggest that Croatian students feel serious doubts when it comes to the future of democracy in Kosovo. On one hand, a part of the respondents claims that in the short run Kosovo authorities will be able to reform the system so that the country will be based on the principles of democracy and will be politically, economically and socially stable. In fact, in the 1990s Croatia itself was an authoritarian country (Tuđman regime) but within a decade it successfully underwent the process of democratization. However, a comparable number of the respondents is of contrary opinion. They argue that Kosovo is overburdened with serious political, economic and social problems which make a swift transformation of the country impossible. Since international community continues to be divided on the issue of Kosovo independence (e.g. lack of China's or Russia's recognition), its authorities are forced to face serious political and economic problems.

The students of the University of Belgrade expressed a viewpoint which was much more clear. $83 \%$ argued that in the next 10 years Kosovo would not become a stable and democratic country. This result overlaps with a general opinion on Kosovo sovereignty ( $83 \%$ as well) which might prove that the students are consequent on that matter. It seems logical that if a respondent expressed a negative opinion on Kosovo independence, their view on Kosovo as a democratic and stable state would also be negative. What is more, it is clearly visible that in comparison with other Serbian regions Kosovo is economically underdeveloped (low economic indicators) as well as politically and socially unstable (Serbian-Albanian conflict in the north of Kosovo). It is also widely believed that without international financial support, Kosovo is unable to function as a separate country; therefore the process of democratization must be carried out under external supervision. For this reason a decade seems much too short to achieve a desired result in the form of a stable and democratic country (Hebda 2015: 262). Only $2 \%$ of the respondents at the University of Belgrade had a contrary opinion while $11 \%$ claimed that it is difficult to predict the future of Kosovo, even in the short term perspective. 
Chart 4. Is Kosovo going to be a stable, democratic country in 10 years time?

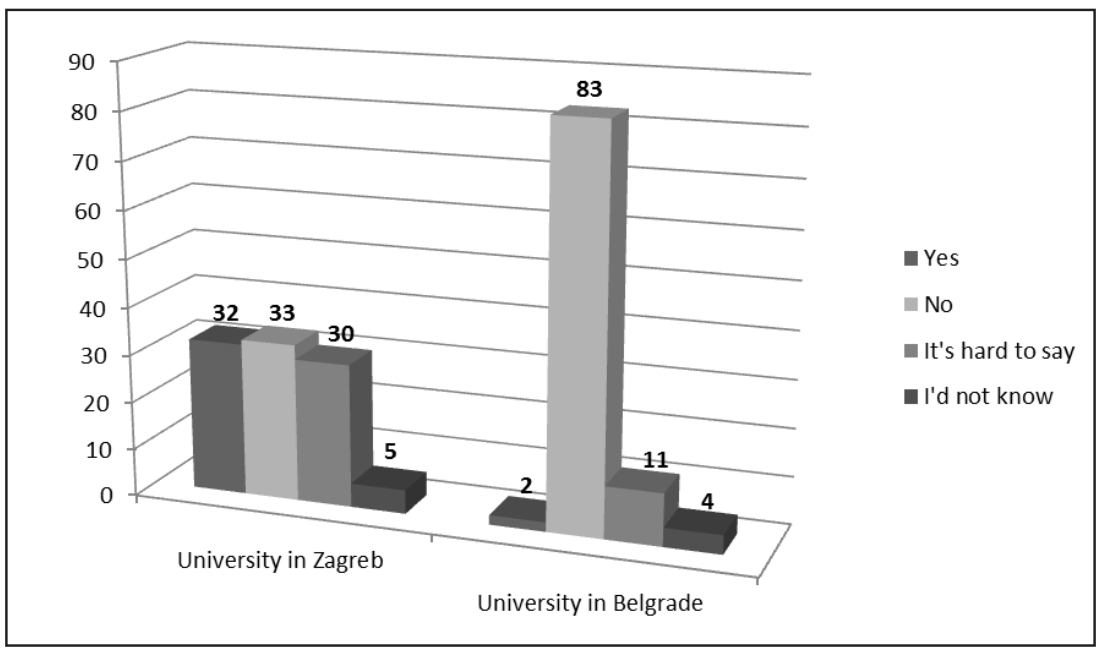

Next question brought up in the research concerned the way Kosovo was supposed to function within the borders of Serbia. This issue directly refers to the legal interpretation of legitimacy of declaration of Kosovo independence. As it has already been mentioned, there are two contradictory stances on the matter. One group claims Kosovo sovereignty is illegal, while the second group argues that Kosovo Albanians proclaimed the independence lawfully. Replies provided by both Croatian and Serbian research group confirm such a division and doubts about Kosovo independence or territorial integrity of Serbia. More than a half of the students of the University of Zagreb (i.e. 56\%) is of the opinion that Kosovo should not exist within Serbian borders. Only $8 \%$ had a contrary opinion while $27 \%$ were unable to define their position on the matter. The majority of the respondents in Croatian research group supports the idea of exempting Kosovo from Serbian jurisdiction, but there is still a significant part with a contrary opinion. This ambiguity seems to contradict the official stand presented by Croatian authorities (if we recognize Kosovo sovereignty, we also support its secession from Serbia), and, what is more, every third respondent $(27 \%)$ is not sure if Kosovo should function within Serbian borders or not. Such a high percentage might result from greater awareness of the surveyed students in respect to legitimacy of Kosovo secession. 
Comparing to the research group from the University of Zagreb, the opinion of Serbian students diverges significantly. More than a half of Serbian respondents (i.e. 55\%) were of the opinion that Kosovo should exist within Serbian borders. Nearly one in four had a contrary opinion while every fifth did not express their opinion. As a matter of fact, both groups constitute $44 \%$ of respondents which might point out to polarization among students' opinions on the matter of territorial integrity of the country as well as the need to keep Kosovo within Serbian borders. The result might also indicate that the unequivocal position of Serbian authorities in respect to territorial integrity does not really have such a big influence on students' view or public opinion in general (obviously, this conclusion does not have to be well-grounded). What is more, in respect to the view on Kosovo independence or Kosovo existence within Serbian borders, the percentage of both Belgrade and Zagreb research group has dropped. It suffices to recall that $83 \%$ of the respondents from the University of Belgrade were against Kosovo sovereignty while "only" 55\% supported the idea of keeping Kosovo within Serbian borders. At the University of Zagreb the proportion was similar. 78\% supported Kosovo sovereignty while "only" 56\% argued that it should not exist within Serbian borders. Such a discrepancy might result from various interpretations of Kosovo status - in a way they do not mean to question Kosovo independence itself, it is rather a matter of what independence is and what it should be. Another hypothesis is that some of those supporting Kosovo independence understand this concept in a wider manner. According to that group, independence should not be about full autonomy but also supervision and on such grounds Kosovo should be function within Serbian state (as autonomy). Also, people who did not accept either Kosovo sovereignty or its existence in Serbia might have perceived Kosovo as an international protectorate or a dependent territory. 
Chart 5. Should Kosovo function within Serbian borders?

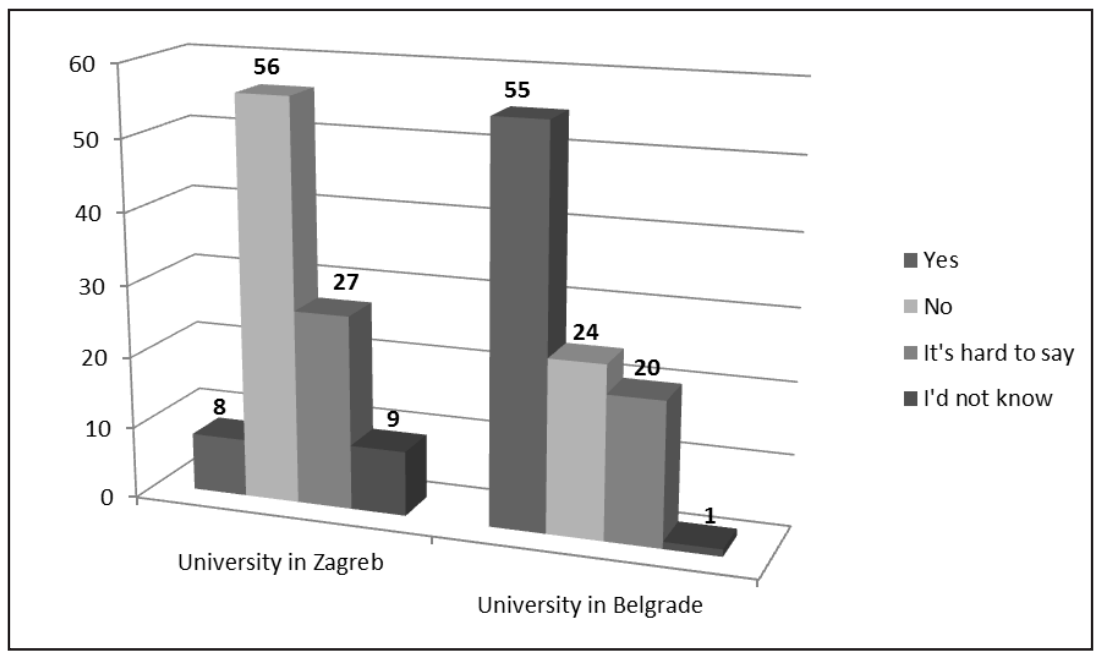

In order to fully understand Kosovo independence one should bear in mind the concept of dividing the area into Serbian and Albanian part (Ker - Lindsay 2011: 231 - 233; Economides, Ker - Lindsay \& Papadimitrious 2010: 106 - 110; Gjoni, Wetterberh \& Dunbar 2010: 306 - 309; Hebda 2014: 14). Dobrica Ćosić, the president of FYR between 1992 and 1993 and a well-known Serbian novelist, was a supporter of the solution. Such a partition was considered in 2009 by the then president of Serbia Boric Tadic and two years later by the deputy prime minister Ivica Dačić. When the Serbian Progressive Party won the elections, the idea of Kosovo partition became less popular (Hebda 2018: 279). The idea still keeps on coming back, especially in the context of tensions in the north Kosovo. Kosovska Mitrovica might serve here as an example. The river Ibar, which flows through the city, divides it into Serbian and Albanian part. The partition prompted multiple acts of violence, for instance the murder of Serbian politician Oliver Ivanovic in January 2018. This issue seems to be really problematic also for the students and neither of the two research groups were able to give clear opinions on the matter. $39 \%$ of the respondents from the University of Zagreb said they held no unequivocal opinion on Kosovo partition while 35\% claimed that dividing Kosovo into Serbian and Albanian part would not provide an effective solution 
of Kosovo conflict. It is speculated that drawing up internal borders in Kosovo and granting a wide autonomy to Kosovo Albanians within the borders of Serbia might have a stabilizing influence (similar solution was applied in case of the Republika Srpska on the territory of Bosnia and Herzegovina). On the other hand, it also seems likely that such a solution would not change much and would encourage Kosovo Albanians to pursue secession. Coming back to the results of the study, only $13 \%$ of the respondents from Zagreb supported the idea of Kosovo partition. Dividing the land and creating Serbian and Albanian territory in Kosovo could improve local sense of security and stabilize mutual relations but such a solution would also call for a constant supervision of third countries or supranational organizations. It is also likely that such a change would only stir up the ethnic conflict in Kosovo and the surrounding areas (Preševo Valley).

The students from the University of Belgrade shared an interesting view on the matter. What is clearly visible is a polarization of opinions on Kosovo partition - 39\% said it was the best solution of Serbian-Albanian conflict. However, only slightly less respondents (38\%) expressed a contrary opinion. Such an outcome is bound to reflect the opinion of Serbian politicians as well as the citizens in respect to Kosovo partition. It is difficult to assess which approach is more popular, however public opinion is clearly divided on this subject. On one hand, Kosovo partition would breach territorial integrity of Serbia which, in the long run, could mean approval for Kosovo independence. Nevertheless, it would also be a chance to incorporate north Kosovo into Serbia which might result in building diplomatic relations between Serbians and Kosovo Albanians on new grounds. Both solutions are likely to produce quite unpredictable results, no matter which concept will prevail. For this reason in particular, one in fifth of the Belgrade respondents did not manage to express their opinion on the matter. 
Chart 6. Is Kosovo partition into Serbian and Kosovo Albanian territory the best solution of the conflict?

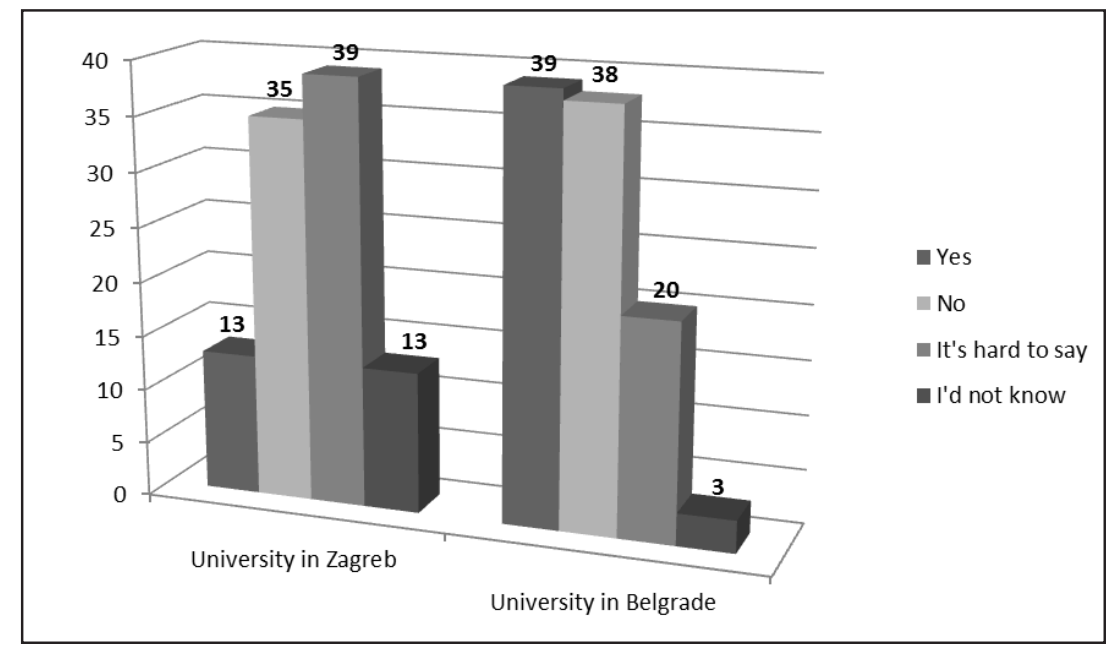

\section{DEBATE}

The research presented in the paper reflects diversity in opinions on Kosovo independence expressed among the students of the University of Zagreb and the University of Belgrade. On one hand, such views overlap with the official stand of Serbian and Croatian authorities but in terms of Serbian territorial integrity or Kosovo partition, a rupture in public opinion is clearly visible. Surely, the case of Kosovo is complicated and generates some legal and political questions raised by both supporters and adversaries of Kosovo independence. It seems that the case has remained in a state of complete deadlock for many years while the dispute has escalated to the international level. As a result, the simplified dual image of Kosovo (legal vs. illegal) is mirrored by the public opinion (in particular inhabitants of ex-Yugoslavia countries). The students of political science at two most important universities in Serbia and Croatia constitute an essential research group, especially in respect to future discussions on Kosovo status. Such a comparison of the research groups from countries which represent contradictory views on the matter (Serbia vs. Croatia) might prove that opinions on Kosovo independence can be changing. Summing up, the hypotheses put 
forward at the beginning of the paper proved to be right (i.e. the students of the Faculty of Political Science at the University of Zagreb are in favor of Kosovo independence, the students of the Faculty of Political Science at the University of Belgrade do not support Kosovo independence). It must be clarified, though, that due to the hypotheses being rather general, they do not clearly reflect real views of both research groups on the matter of Kosovo independence. Nevertheless, the results show that Kosovo case is a discriminatory issue conflicting not only politicians but also various social groups, which, in turn, might threaten regional security. It shows major social disagreements about security structure of the region itself, and moreover about regional cooperation processes, and which consequences this might have.

As was mentioned at the outset, young people (students in 2013, and now graduates aged about 30 working in government administration, non-governmental organizations, media, think tanks, consulting firms and so on) are a social group that shapes current political debate on the status of Kosovo. The quality of this dialogue and its effects may have a significant impact on future security the CEE region.

\section{REFERENCES}

Avramović, S., D. Rakitić, M. Menković, V. Vasić, A. Fulgosi \& B. Jokić. 2010. The Predicament of Serbian Orthodox Holy Places in Kosovo and Metohia. Elements for Historical, Legal and Conservational Understanding. Belgrade: University of Belgrade Faculty of Law.

Cerone, J. 2008. „The Legality and Legal Effect of Kosovo’s Purported Secession and Ensuing Act of Recognition". Annals of the Faculty of Law in Belgrade - International Edition, 3: $60-71$.

Crnić-Grotić, V. \& D. Kasipović. 2013. „The Right to Self-Determination - The Kosovo Case before the International Court of Justice“. Zbornik Pravnog fakulteta Sveučilišta u Rijeci, 34(2): 895-910. 
Даниловић, Н. С. \& А. Н. Благојевић Даниловић. 2019. „Агресија НАТО на Савезну Републику Југославију - 20 година после: политиколошко правни аспекти“. Политика националне безбедности, 1/2019: 141-173.

Economides, S., J. Ker - Lindsay, \& D. Papadimitrious. 2010. „Kosovo: Four futures“. Survival, 52(5): 99-116.

Гаћиновић, Р. 2017. „Утицај сецесије Косова и Метохије на националну безбедност Србије“. Политика нащионалне безбедности, 2/2017: 69-86.

Gjoni, R., A. Wetterberg \& D. Dunbar. 2010. „Decentralization as a conflict transformation tool: The challenge in Kosovo". Public Administration and Development, 30(5): 291-312.

Hebda, W. 2014. „The Issue of Problematic States: Kosovo - A Failed State? Political and Economic Analysis - Outline of Problem". American International Journal of Social Science, 3(4): 210-218.

Hebda, W. 2015. „Kosowo - droga do niepodległości (1999-2008)“. Społeczeństwo i Polityka 4(45): 250-263.

Hebda, W. 2018. Serbsko - chorwackie stosunki polityczne na przetomie XX i XXI wieku. Warszawa: Oficyna Wydawnicza ASPRA-JR.

International Court of Justice. 2010. Reports of Judgments, Advisory Opinions and Orders. Accordance with International Law of the Unilateral Declaration of Independence in Respect of Kosovo. Advisory Opinion of 22 July 2010.

Jovanović, M. 2008. Recognition of Kosovo Independence as a Violation of International Law. Annals of the Faculty of Law in Belgrade - International Edition, 3: 108-140.

Ker-Lindsay, J. 2011. „Principles and the partition of Kosovo“. Peace Review: A Journal of Social Justice, 23(2): 228-234.

Komorowski, P. 2011. „Niepodległe Kosowo, prawo międzynarodowe i prawa człowieka - próba odnalezienia wspólnego mianownika“. Polski Rocznik Prawa Człowieka i Prawa Humanitarnego, 2: 63-87. 
Крга, Б. 2017. „Проблем Косова и Метохије и политика националне безбедности Републике Србије“. Политика националне безбедности, 2/2017: 49-68.

Petričušić, A. 2009. „Ethno - Mobilisation and its Consequences in Croatia“. Southeastern Europe, 34: 1-23.

Петров, В. 2018. „Којим путем после унутрашњег дијалога о КиМ?“. Политика националне безбедности, 1/2018: 9-21.

Security Council. 1999. Rambouillet Accords. Interim Agreement for Peace and Self-Government in Kosovo. Security Council, S/1999/648.

Sterio, M. 2010. „Creating and Building a “State” International Law and Kosovo". Proceedings of the ASIL Annual Meeting, 104: 361-365.

Ustav Republike Srbije. 2006. Službeni glasnik RS, br. 98/2006. 


\section{Виктор Хебда}

Институт за политичке науке и међународне односе, Јагелонски универзитет, Краков, Пољска

\section{СТАТУС КОСОВА ПРЕМА СТАВОВИМА СТУДЕНАТА УНИВЕРЗИТЕТА У ЗАГРЕБУ И УНИВЕРЗИТЕТА У БЕОГРАДУ}

\section{Резиме}

Питање независности Косова је и даље кључна тема на глобалној скали. Једноставно представљено, постоје два контрадикторна става о суверенитету Косова. Према првом, косовско проглашење независности је кршење међународног права и Устава Републике Србије. Друго становиште сматра да је једнострано проглашене независности легално јер косовски Албанции имају право на самоопредељење. Рад представља ставове о независности Косова сакупљене на основу истраживања јавног мњења у којем су учествовали студенти Факултета политичких наука Универзитета у Београду и Факултета политичких знаности Свеучилишта у Загребу - два највећа и најважнија универзитета у Србији и Хрватској. Резултати су базирани на истраживању које је аутор обавио током 2013. године.

Кључне речи: Косово, Хрватска, Србија, суверенитет, територијални интегритет

\footnotetext{
* wiktor.hebda@uj.edu.pl

* Овај рад је примљен 14. марта 2020. године, а прихваћен за штампу на телефонском састанку Редакције, 13. априла 2020. године.
} 